\title{
Barriers to Creativity, Identification and Inclusion of Gifted Student
}

\author{
Fernanda Hellen Ribeiro Piskeㄹ, Tania Stoltz' ${ }^{1}$ Carla Luciane Blum Vestena ${ }^{2}$, \\ Samarah Perszel de Freitas ${ }^{3}$, Bernadete de Fátima Bastos Valentim ${ }^{4}$, \\ Carla Sant'ana de Oliveira5, Ana Aparecida de Oliveira Machado Barby², \\ Cristiana Lopes Machado ${ }^{1}$ \\ ${ }^{1}$ Federal University of Parana, Curitiba, Brazil \\ ${ }^{2}$ Unicentro/UFPR, Guarapuava, Brazil \\ ${ }^{3}$ Positivo University, Curitiba, Brazil \\ ${ }^{4}$ Unicentro/Federal University of Parana, Guarapuava, Brazil \\ ${ }^{5}$ Unicentro/Faculdade Guairacá, Guarapuava, Brazil \\ Email: nandahellen@hotmail.com
}

Received 23 June 2016; accepted 22 August 2016; published 25 August 2016

Copyright (C) 2016 by authors and Scientific Research Publishing Inc.

This work is licensed under the Creative Commons Attribution International License (CC BY). http://creativecommons.org/licenses/by/4.0/

(c) (i) Open Access

\begin{abstract}
At most time, gifted student remains hidden in the classroom, without voice and no right to a quality education. The current educational reality can be considered a barrier to the development of creativity at school and the worst thing is that this student often does not have access to specialized service because he/she is not identified. In this sense, this research aims to highlight opportunities of identification and inclusion for gifted children. The conclusion is that the elucidation of the gifted child's needs can help many teachers to improve teaching strategies that foster creativity of this child and incite their curiosity and their desire to learn. From the moment that this child is identified, there will be the possibility of having access to specialized service so that their special needs can be attended. It is essential that teachers are prepared to promote a quality education that attends each dimension of development of gifted student. This way is possible to identify and include this child at school.
\end{abstract}

\section{Keywords}

Identification, Inclusion, Creative Child

\section{Introduction}

The gifted child is creative and generally he/she uses his/her creativity to solve his/her activities in the school 
context. Not always his/her creativity is worked during the classes, and one of the reasons for the absence of creative practices is that some teachers are not trained to prepare classes that encourage imagination and creativity of his/her students. It means the way to deal with barriers to creativity is still unresolved.

The current educational reality can be considered a barrier to the development of creativity at school. Stoltz (2016) explains that coexist initiatives for a resistance state in reductionist way of understanding the educational phenomenon, but fall into another extreme: the practice by practice. The author points out that often the educational process is limited to what the student already knows and dominates, hindering him/her even from realizing the role of the school and its importance. This situation represents something very corrosive to the students with high abilities/giftedness.

Stoltz (2016) points out that the indices of absences and school escape are a consequence. Both the emphasis on early intellectuality and practice by practice are reductionist ways of understanding education and contribute to the current state of losing sight of what is important in education. Emphasis on early intellectuality can hinder individuals to use their creativity.

\section{Some Barriers to Creativity of Gifted Students}

According to some studies (Alencar \& Fleith, 2001; Pérez, 2004, 2009; Piske, 2013a, 2013b, 2014a, 2014b, 2016; Piske, Stoltz, \& Machado, 2014a, 2104b; Machado, 2013) it is possible to make a list of some barriers that hinder the development of creativity of gifted individuals, such as:

- Repetitive teaching;

- Uniformity of knowledge;

- Teachers who are not prepared to make a class that incite curiosity and interest of learning of their gifted students;

- Traditional process of teaching and learning;

- Reductionist way of understanding the educational context;

- Lack of creativity and innovation during classes.

\section{Barriers that Hinder the Identification of Gifted Students}

In the school context, there are barriers that can hinder the gifted child to be identified. During the process of teaching and learning there is a lack of reflection about knowledge that still remains in many schools, there is resistance about differences and diversity of students, there is an absence of challenges and activities that promote the development of creativity, there is a lack of recognition by education professionals in relation the high abilities of their students, among other issues that can mean the hindrance of identification of gifted students.

According to Alencar (2009, 2014), Virgolim (2007) \& Pérez (2004) it is possible to list some of the barriers to identification of gifted child, as follow:

- traditional view of education centered on the transmission of information and not in reflection about knowledge;

- disrespect of differences and uniformity of knowledge;

- lack of sufficient challenges in the school environment;

- difficulty of recognition among educators about high abilities of their students;

- gifted students with hearing impairment, neurological impairment, motor impairment and other special needs;

- stereotypical expectations regarding deficiencies;

- delays in physical and psychological development, asynchrony;

- incomplete information about abilities;

- unfamiliarity on the part of educators about multiple forms of enrichment, with a view to the development of abilities of their students.

It is important that the school is prepared to understand the abilities and interests of students, as well as their specificities and needs in each dimension of development. According to Virgolim (2007), it is fundamental: know the potential and interests of the students, their cognitive, social and affective needs in order to give them opportunities to make their own knowledge, at their own pace (Virgolim, 2007: p. 9-10).

The comprehension that the gifted child requires special attention for presenting educational needs that must be attended is essential so that he/she can have access to quality education. The identification of the child just depends on the way he/she is understood by professionals that work with him/her. These professionals should 
have a sensitive look at specificities of their gifted students.

\section{How to Deal with Barriers to Creativity?}

It is necessary that the teaching staff is prepared to create a stimulating environment of creativity. The class should be prepared creatively to awaken the interest of gifted students and their willingness to learn. For this, teachers need to know the interests and specificities of their students, for example, if the student likes to draw, it is important that the activities focus on draw, if the student likes to make researches, activities involving researches are essential for this student to learn. In general, working with art can be a good option to develop creativity.

Another way to work with creativity can be the ludic teaching (Brougère, 2000). According to Piske (2016) it is possible to emphasize the importance of ludic teaching to attend psychological, cognitive, emotional and social needs of gifted students, education should attend the desire to learn and area of interest of these children to enable their welfare and development their creative potential.

\section{Some Difficulties to Identify and Include Gifted Children at School}

By school reality, it is increasingly difficult to identify someone with high potential. The gifted child often remains hidden in the classroom, without voice and no right to a good education. And the worst is that this child does not have access to specialized service because he/she is not identified. It is important to rely on support of good professionals able to understand that gifted students have special needs to be attended.

Melo \& Almeida (2007), Bahia \& Trindade (2013, 2014), Bahia (2016), Piske $(2015,2016)$ points out that we are still far short of experiencing a quality education that respects the rights of children with special needs, such as the gifted children with special needs that are not always attended. It is important that exists a society who is able to mobilize in favor of the rights of these children, when it comes to gifted students, the first step would be to identify and make a diagnosis of them so that they have the opportunity to attend the specialized service.

It is essential that children with special needs have access to a quality education in regular schools, as stated in the UNESCO, Salamanca Statement (1994): Inclusive schools must recognize and respond to the diverse needs of their students [...] (UNESCO, Salamanca Statement, 1994: p. 11).

It is important that there is a political commitment, both nationally and society to ensure adequate resources and reorient existing ones. These resources can be material and personnel to carry out inclusive education with quality.

Material resources can be considered: the areas and rooms of specialized service, as well as suitable materials so that this service can take place, and the personal resources are defined by the efficient work of professionals prepared to attend students with special needs. According to UNESCO, Salamanca Statement (1994):

The development of inclusive schools as the most effective means for achieving education for all must be recognized as a key government policy and accorded a privileged place on the nation's development agenda. It is only in this way that adequate resources can be obtained. Changes in policies and priorities cannot be effective unless adequate resource requirements are met. Political commitment, at both the national and community level, is needed both to obtain additional resources and to redeploy existing ones. While communities must play a key role in developing inclusive schools, government encouragement and support is also essential indevising effective and afford able solutions (UNESCO, Salamanca Statement, 1994: p. 41).

Despite appearing in Salamanca statement the importance of including children with special needs in the school context, we are still far short of having a full inclusion that attends every dimension of development of gifted child.

\section{How to Identify This Creative Child?}

Regarding the identification of gifted, one of the main authors of the area of high abilities/giftedness is Joseph Renzulli. In his model of the three rings this author highlights three aspects that are present in the gifted child.

Renzulli (2004) points out the importance of such following aspects: above average ability, task commitment and creativity. Each one has an important role for the identification of gifted students' behaviors (Piske, 2013a, 2014a). 
The model of Three Rings of Renzulli (1988) states that "[...] gifted students behaviors are manifestations of human performance that can be developed in certain people at certain times and under certain circumstances" (Renzulli, 1988: p. 20).

Renzulli $(2000,2004)$ explains that above average abilities can refer to general abilities and specific abilities, example of general abilities: abstract thinking, processing information, integrating experiences, and example of specific abilities: perform in an activity, the capacity to acquire knowledge.

Regarding creativity, this aspect is related to sensitivity to stimulations, fluency, flexibility, and originality of thought, and a willingness to take risks (Renzulli, 2004).

Renzulli (2000) points out that task commitment refers to motivation turned into action, some examples: endurance, hard work, perseverance, self-confidence, perceptiveness and a special fascination with a special subject.

Another model to identify gifted students is presented by Pfeiffer (2016). His model of giftedness is: "The tripartite model of giftedness." The author explains that each of the three aspects of his model is complementary, and provides an understanding of the strengths of students to determine the appropriate assessment and intervention procedures. These three aspects are:

- Giftedness through the lens of high intelligence;

- Giftedness through the lens of outstanding accomplishments;

- Giftedness through the lens of potential to excel.

Pfeiffer (2016) explains that the gifted perspective which is probably most familiar to readers is giftedness through the lens of High Intelligence. Gifted individuals from this perspective have elevated and superior intellectual and cognitive abilities. In childhood, these students typically have IQ scores in the top 2\% - 5\%.

Pfeiffer (2016) points out that a second and alternative way to view giftedness using the tripartite model is through the lens of Outstanding Accomplishments. This second lens emphasizes individuals' performance on actual academic tasks and products; individuals who shine and excel in the classroom and on academic measures are considered gifted within this second gifted categorization. This second view does not discount the importance of high IQ, but IQ is not considered a core feature of this second group of students.

Pfeiffer (2016) highlights that the third perspective through which one can view giftedness in the tripartite model is The Potential to Excel. This perspective empowers students who may not have been provided with the proper opportunities, environments, or resources in childhood, and who may have as yet under-developed intellectual or academic abilities. According to Pfeiffer (2016) students are considered gifted applying this third perspective if they demonstrate uncanny potential to succeed and develop superior abilities compared to their peers (Pfeiffer, 2016).

\section{Characteristics of Gifted Children}

The identification of the gifted child may depend on the preparation of the teaching staff to understand their characteristics. Overall, this child likes challenges, he/she uses his/her creativity, independent thinking, skills in specific areas, not necessarily academic, he/she presents fast learning with minimal instruction, among other characteristics that can be a support for their identification.

Activities that represent challenges are essential during classes, because they make the child think about how to find the solution to some activity or solution for a problem. During the process of resolving an issue, this child often seeks solutions in a creative way that is not always the same way as their teachers ask in class.

A monotonous teaching can mean a barrier to develop creativity of gifted child. Deal with the special needs of children with high potential can be something more complex than many teachers think. Generally, gifted child has independence of thought, he/she does not usually follow a standardized education and much less a repetitive teaching, he/she likes innovation, creation and invention during learning (Stoltz et al., 2015).

Authors of the area of High Abilities/Giftedness point out some characteristics that may help teachers to identify gifted children (Alencar \& Fleith, 2001; Fleith, 2007; Pérez, 2004, 2009; Piske, 2013a, 2013b, 2014a, 2014b, 2016; Piske, Stoltz, \& Machado; 2014a, 2104b, Machado, 2013; Renzulli, 2000, 2005; Besançon, Guignard \& Lubart, 2006; Gross, 2014, 2016; Kane \& Silverman, 2014; Piechowski, 2014, Valentim, 2015; Valentim, Vestena, \& Neumann, 2014; among other authors).

These characteristics can be identified in the family environment and at school from the moment that the gifted child starts attending school or during his/her experience in different contexts, they may manifest in a iso- 
lation way or in combination with other characteristics. It is possible to make a list with these characteristics as follows:

- independence of thought;

- preference for challenge;

- creativity;

- language acquired since childhood, fast progressing to complex sentences, with abundant vocabulary and high capacity verbal knowledge;

- abilities in specific areas, not necessarily academic.

- early physical development: sitting, crawling and walking before the time considered normal;

- intellectual curiosity, interesting questions and persistence to achieve the desired information;

- fast learning with minimal instruction (little help and few stimulus of adults);

- high persistence and concentration when they are interested;

- high level of energy, which can lead to hyperactivity when they are insufficiently stimulated (sometimes they need less sleep time than normal for age);

- interests in specific areas with a high level of commitment to become experts in these areas;

- developed sense of humor;

- sensitivity to social problems and feelings of other people;

- high level of moral development;

- high ability in the area of his/her interest (Alencar \& Fleith, 2001; Fleith, 2007; Pérez, 2004, 2009).

The training of the teaching staff on identifying and attending the gifted child will reflect on the method of preparation in their classes and on how to deal with their special educational needs. The more preparation of teachers in dealing with these needs, the more they will understand the characteristics that this child may have in the school context, this way these teachers will be able to carry out a work to develop his/her creativity and instigate his/her curiosity and interest in learning.

Kane (2016) points out that, in 2005, Vialle and Quigley made a research with 857 gifted students in Australia, Austria, and the United States. Their research found that effective characteristics of teachers of gifted and talented can be grouped into three themes: interpersonal, teaching and classroom management style, and intellectual qualities. They gleaned these characteristics from the research literature on effective teachers of the gifted. These characteristics were listed as follows:

Characteristic about personal/Social: being culturally responsive; having insights into the cognitive, social, and emotional needs of gifted students; being willing to make mistakes; possessing a sense of humor; being enthusiastic.

Regarding characteristic about teaching Strategies/Approach: being well organized; having skills in differentiating the curriculum for gifted students; employing strategies that encourage higher level thinking; encouraging students to be independent learners; providing student-centered learning opportunities; acting as a facilitator or "guide on the side"; creating a non-threatening learning environment.

Regarding intellectual-Cognitive Characteristic: possessing in-depth knowledge of subject matter; having broad interests, often literary and cultural; having above-average intelligence; being a lifelong learner; thinking creatively; possessing excellent communication skills (Kane, 2016).

Kane (2016) explains that the teaching staff can be based on these characteristics above mentioned to enhance and improve their qualities during classes. If teachers are aware that they may have some of these characteristics in favor of a quality education, professional development can become a personal journey towards excellence rather than an imposed practice.

In relation to teacher training, their preparation is essential to have inclusion of gifted child. Without proper training, these professionals will not be prepared to identify and attend this child. Salamanca Statement makes clear the importance of teacher preparation for the specialized service of children with special needs, according to the following statement:

Resources must also be allocated to support services for the training of mainstream teachers, for the provision of resource centres and for special education teachers or resource teachers. Appropriate technical aids to ensure the successful operation of an integrated education system must also be provided. Integrated approaches should, therefore, be linked to the development of support services at central and intermediate levels (UNESCO, Salamanca Statement, 1994: p. 42). 


\section{Conclusion}

Barriers to creativity, identification and inclusion of gifted child are linked to lack of proper training of education professionals.

The comprehension about gifted child's needs can help many teachers to prepare efficient teaching strategies that foster creativity of this child and awaken his/her curiosity and his/her desire to learn (Piske, 2015). From the moment that this child is identified, there will be possibilities of being sent to specialized service so that special needs are attended.

It is notorious that it is not enough to identify a gifted child. Besides being identified, it is essential that the school has full inclusion measures for this child, and offers teaching that can instigate his/her imagination and creativity.

Stoltz (2016) explains that imagination allows the experience of totality, in a world that has lost the dimension of the whole and it is lost in the fragmentation of existence without finding way out unless the emptiness and nothingness. The author explains that several studies claim the need for imagination development in education, but few studies offer resources for this development. Moreover, Piske (2015) points out that the lack of material and human resources can hinder to identify and attend the gifted child. It is essential to count on good education professionals prepared to promote a quality education that attends each dimension of development of gifted student. Only in this way will it be possible to identify and include this child at school.

\section{References}

Alencar, E. M. L. S. (2009). Como desenvolver o potencial criador: Um guia para a liberação da criatividade em sala de aula. Petrópolis, RJ: Vozes.

Alencar, E. M. L. S. (2014). Ajustamento Emocional e Social do Superdotado: Fatores Correlatos. In F. H. R. Piske et al. (Orgs.), Altas habilidades/Superdotação (AH/SD): Criatividade e emoção (pp. 149-162). Curitiba: Juruá.

Alencar, E. M. L. S., \& Fleith, D. S. (2001). Superdotados: determinantes, educação e ajustamento. São Paulo: EPU.

Bahia, S. (2016). Criatividade na avaliação e intervenção na sobredotação. In F. H. R. Piske et al. (Orgs.), Altas habilidades/Superdotação (AH/SD) e Criatividade: Identificação e Atendimento (pp. 145-164). Curitiba: Juruá.

Bahia, S., \& Trindade, J. P. (2013). Transformar o velho em novo: A integração da criatividade na educação. In Piske, F. H. R., \& Bahia, S. (Orgs.), Criatividade na escola: O desenvolvimento de potencialidades, altas habilidades e talentos, emoção (pp. 15-32), Curitiba: Juruá.

Bahia, S., \& Trindade, J. P. (2014). A importância da cooperação na sobredotação. In F. H. R. Piske et al. (Orgs.), Altas habilidades/Superdotação (AH/SD): Criatividade e emoção (pp. 115-126). Curitiba: Juruá.

Besançon, M., Guignard, J. H., \& Lubard, T. (2006). Haut potentiel, créativité chez l'enfant et éducation. Bulletin de Psychologie, 59, 491-504. http://dx.doi.org/10.3917/bupsy.485.0491

Brougère, G. (2000). Brinquedo e cultura (3rd ed., 110 p). São Paulo: Cortez.

Fleith, D. S. (2007). Altas habilidades e desenvolvimento socioemocional. In D. S. Fleith, \& E. M. L. S. Alencar (Orgs.), Desenvolvimento de talentos e altas habilidades: Orientação a pais e professores (pp. 41-50). Porto Alegre: Artmed.

Gross, M. U. M. (2014). Issues in the Social-Emotional Development of Intellectually Gifted Children. In F. H. R. Piske et al. (Orgs.), Altas habilidades/Superdotação (AH/SD): Criatividade e emoção (pp. 85-96). Curitiba: Juruá.

Gross, M. U. M. (2016). Developing Programs for Gifted and Talented Students. In F. H. R. Piske et al. (Orgs.), Altas habilidades/Superdotação (AH/SD) e Criatividade: Identificação e Atendimento (pp. 61-76). Curitiba: Juruá.

Kane, M. (2016). Gifted Learning Communities: Effective Teachers at Work. In F. H. R. Piske et al. (Orgs.), Altas habilidades/Superdotação (AH/SD) e Criatividade: Identificação e Atendimento (pp. 77-94). Curitiba: Juruá.

Kane, M., \& Silverman, L. K. (2014). Fostering Well-Being in Gifted Children: Preparing for an Uncertain Future. In F. H. R. Piske et al. (Orgs.), Altas habilidades/Superdotação (AH/SD): Criatividade e emoção (pp. 67-84). Curitiba: Juruá.

Machado, J. M. (2013). Habilidades cognitivas e metacognitivas do aluno com altas habilidades/superdotação na resolução de problemas de matemática. Tese (Doutorado em Educação). Curitiba: Universidade Federal do Paraná.

Melo, A. S., \& Almeida, L. S. (2007). A identificação precoce da sobredotação: Alguns problemas e propostas. Sobredotação, 8, 27-43.

Pérez, S. G. P. B. (2004). Gasparzinho vai à escola: um estudo sobre as características do aluno com altas habilidades produtivo-criativo. Mestrado em Educação Dissertação, Porto Alegre: Faculdade de Educação, Pontifícia Universidade Católica do Rio Grande do Sul.

Pérez, S. G. P. B. (2009). A identificação das altas habilidades sob uma perspectiva Multidimensional. Revista Educação 
Especial, 22, 299-328. http://cascavel.ufsm.br/revistas/ojs-2.2.2/index.php/educacaoespecial/article/view/811/555

Pfeiffer, S. (2016). Leading Edge Perspectives on Gifted Assessment. In F. H. R. Piske et al. (Orgs.), Altas Habilidades /Superdotação (AH/SD) e Criatividade: Identificação e Atendimento (pp. 95-122). Curitiba: Juruá.

Piechowski, M. M. (2014). Identity. In F. H. R. Piske et al. (Orgs.), Altas Habilidades/Superdotação (AH/SD): Criatividade e emoção (pp. 97-114). Curitiba: Juruá.

Piske, F. H. R. (2013a). O desenvolvimento socioemocional de alunos com altas habilidades/superdotação (AH/SD) no contexto escolar: contribuições a partir de Vygotsky (166 p). Mestrado em Educação Dissertação, Curitiba: Universidade Federal do Paraná.

Piske, F. H. R. (2013b). Criatividade no Processo de Aprendizagem de Superdotados. In III Seminário Internacional de Educação de Pinhais (pp. 1-12).

Piske, F. H. R. (2014a). O desafio de promover práticas educacionais para atender a alunos superdotados. In $I V$ Seminário Internacional de Educação de Pinhais (pp. 1-11).

Piske, F. H. R. (2014b). Criatividade e inovação na educação de superdotados. In F. H. R. Piske et al. (Orgs.), Altas Habilidades/Superdotação (AH/SD): Criatividade e emoção (pp. 265-276). Curitiba: Juruá.

Piske, F. H. R. (2015). Aluno (a) com altas habilidades/superdotação (AH/SD): quem é essa criança? In IV Seminário Internacional de Educação de Pinhais (pp. 1-12).

Piske, F. H. R. (2016). Alunos com Altas Habilidades/Superdotação (AH/SD): como identificá-los? In F. H. R. Piske et al. (Orgs), Altas Habilidades/Superdotação (AH/SD): Criatividade e emoção (pp. 249-260). Curitiba: Juruá.

Piske, F. H. R., Stoltz, T., \& Machado, J. (2014a). Creative Education for Gifted Children. Creative Education, 5, $347-352$. http://file.scirp.org/pdf/CE 2014042316202374.pdf

Piske, F. H. R., Stoltz, T., \& Machado, J. (2014b). Creative Educational Practices for Inclusion of Gifted Children. Creative Education, 5, 803-808. http://file.scirp.org/pdf/CE_2014061915205191.pdf

Renzulli, J. S. (1988). Technical Report of Research Studies Related to the Enrichment Triad/Revolving Door Model (3rd ed.). Storrs, CT: University of Connecticut, Teaching the Talented Program.

Renzulli, J. S. (2000). Enriching the Curriculum for All Students. Mansfield Center, CT: Creative Learning Press.

Renzulli, J. S. (2004). O que é esta coisa chamada superdotação e como a desenvolvemos? Retrospectiva de vinte e cinco anos. Revista Educação (Porto Alegre), 27, 75-134.

Renzulli, J. S. (2005). The Three-Ring Conception of Giftedness: A Developmental Model for Creative Productivity. In: R. Sternberg, \& J. Davidson (Eds.), Conception of Giftedness (pp. 246-279). Cambridge: University of Cambridge. http://dx.doi.org/10.1017/CBO9780511610455.015

Stoltz, T. (2016). Imaginação e criatividade na educação: a necessidade de outro olhar. In F. H. R. Piske et al. (Orgs), Altas Habilidades/Superdotação (AH/SD): Criatividade e emoção (pp. 191-206). Curitiba: Juruá.

Stoltz, T., Piske, F. H. R., Freitas, M. F. Q., D’Aroz, M. S., \& Machado, J. M. (2015). Creativity in Gifted Education: Contributions from Vygotsky and Piaget. Creative Education, 6, 64-70. http://dx.doi.org/10.4236/ce.2015.61005 http://www.scirp.org/journal/cehttp://dx.doi.org/10.4236/ce.2015.61005

UNESCO, Salamanca Statement. (1994). Declaração de Salamanca e Linha de Ação sobre Necessidades Educativas Especiais. Brasília: Corde.

Valentim, B. F. B. (2015). Análise da noção de justiça em estudantes com altas habilidades/superdotação: uma contribuição educacional (148 p). Mestrado em Educação Dissertação, Guarapuava: Universidade Estadual do Centro-Oeste.

Valentim, B. F. B., Vestena, C. L. B., \& Neumann, P. (2014). Educadores e estudantes: Um olhar para a afetividade nas altas habilidades/superdotação. Revista de Educação Especial, 27, 713-724.

http://dx.doi.org/10.5902/1984686X14421

Virgolim, A. M. R. (2007). Altas Habilidades/Superdotação: encorajando potenciais. Brasília: Ministério de EducaçãoMEC, Secretária de Educação Especial-SEESP. 


\section{Submit or recommend next manuscript to SCIRP and we will provide best service for you:}

Accepting pre-submission inquiries through Email, Facebook, LinkedIn, Twitter, etc.

A wide selection of journals (inclusive of 9 subjects, more than 200 journals)

Providing 24-hour high-quality service

User-friendly online submission system

Fair and swift peer-review system

Efficient typesetting and proofreading procedure

Display of the result of downloads and visits, as well as the number of cited articles

Maximum dissemination of your research work

Submit your manuscript at: http://papersubmission.scirp.org/ 